Conference Paper

\title{
Cytotoxicity Effects of Vitamin C on Cancer Cells MCF-7
}

\author{
Endang Purwaningsih ${ }^{1 *}$, Samsul Mustofa ${ }^{1}$, Pendrianto ${ }^{2}$ \\ ${ }^{1}$ Department of Anatomy, Faculty of Medicine, YARSI University, Jakarta \\ ${ }^{2}$ Telomere Study Center, YARSI University Research Institute, YARSI University, Jakarta
}

${ }^{*}$ Corresponding author:

E-mail:

endang.purwaningsih@yarsi.ac.id

\begin{abstract}
Vitamin C (ascorbic acid) is a powerful antioxidant that can reduce the effects of oxidative stress. One of the diseases caused by oxidative stress is cancer. The study aimed to assess the cytotoxic effect of vitamin C on MCF7 cancer cell cultures. This study used an in vitro laboratory experiment using MCF-7 breast cancer cell culture. MTS assay method was used to test the dose variance of vitamin C (l-ascorbic acid) against MCF-7 cultures. The MTS test used the CellTiter 96 Aqueous One Solution Cell Proliferation Assay kit. After that, 24 and 48 hours of culture were observed using test doses, 0 (negative control, $\mathrm{K}(-)), 10,20,40,80,160,320 \mathrm{~g} / \mathrm{mL}$. The results showed the higher the dose given, the lower the viability of MCF7 cells, both at 24 and 48 hours of incubation. The lowest viability was obtained at $86.75 \%$ at a dose of 320 $\mathrm{g} / \mathrm{mL}$ during incubation for 24 hours and $7.95 \%$ at a dose of $320 \mathrm{~g} / \mathrm{mL}$ during incubation for 48 hours. In conclusion, vitamin $\mathrm{C}$ has a cytotoxic effect on MCF-7 cell culture with an IC50 value of $140 \mathrm{~g} / \mathrm{mL}$. Further research is needed to determine the effectiveness of vitamin $\mathrm{C}$ on the expression of the telomerase enzyme in breast cancer cells, especially MCF-7.
\end{abstract}

Keywords: Vitamin C, MCF 7, viability, MTS

\section{Introduction}

Cancer is one of the leading causes of death worldwide (Momenivahed \& Salehiniya, 2017; Momenivahed \& Salehiniya, 2019). In 2008, there were 8 million deaths from malignant disease, and this figure is expected to reach 11 million by 2030 (Benson \& Jatoi, 2012). Worldwide, it is estimated that there will be around 19.3 million new cancer cases and nearly 10 million cancer deaths in 2020 (Sung et al., 2021). Breast cancer has the highest rank (11.7\%), followed by lung cancer (11.4\%), and occupies about $6.9 \%$ as the cause of cancer death worldwide (Sung et al., 2021).

Breast cancer is a multifactorial disease and occurs worldwide, but the incidence, mortality, and survival rates vary widely in different parts of the world. The mortality rate from breast cancer is higher in underdeveloped countries than in developed countries. This can be influenced by various factors such as population structure, lifestyle, genetic, reproductive, and hormonal factors (Zendehdel et al., 2018; Momenivahed \& Salehiniya, 2019).

Cancer is formed through the change of normal cells into cancer cells due to mutations caused by various factors, including Reactive Oxygen Species (ROS) compounds that are formed in the body (Phaniendra et al., 2015). Reactive Oxygen Species (ROS) are free radicals that play an important role in several physiological processes of the body's organs. On the other hand, free radicals can cause damage to lipids, proteins, and DNA which can lead to increased oxidative stress. This mechanism occurs in several diseases such as cardiovascular, premature aging, and cancer (Bartosz \& Bartosz, 2014; Phaniendra et al., 2015).

Cancer treatment in Indonesia currently uses modern or conventional (medical) methods, including surgery, hormone treatment such as chemotherapy, and radiotherapy (Fitriatuzakiyah 
et al, 2017). Optimal treatment outcomes for breast cancer depend on timely diagnosis followed by an organized multidisciplinary treatment approach. However, in many low-and middle-income countries, effective pathways of care management may be difficult (Mutebi et al., 2020). Until now, there are still many problems in the treatment of tumors or cancers, including not being sensitive to antiproliferative signals and being able to avoid the apoptotic program, resulting in frequent failures and recurrences. Changes in the regulation of the tumor or cancer cell cycle due to genetic instability can lead to the failure of tumor cells to perform the apoptotic function (Harper et al., 2010; Putra et al., 2011).

Another alternative to prevent the accumulation of free radicals is needed antioxidants to inhibit the formation of free radicals in the body. Antioxidants can be produced endogenously or exogenously. Endogenous antioxidants produced in the body include ubiquinone and glutathione. While exogenous antioxidants include vitamin C and vitamin E (Rao \& Moller, 2011). Based on the list of essential drugs according to WHO, vitamin $\mathrm{C}$ is generally used as one of the most important dietary supplements and as a drug that is safe for the body's health. This antioxidant supplement plays an important role in the process of tissue repair, produces neurotransmitters through enzymatic mechanisms, and modulates the immune system (Gonzales et al., 2014).

Vitamin $\mathrm{C}$ and its derivatives have been shown to inhibit the growth of more than seven types of cancer cells, without inducing cytotoxic effects on normal cells such as fibroblasts. It has been further demonstrated that the cytotoxic effect of vitamin $\mathrm{C}$ on cancer cells is related to its prooxidant properties caused inhibition of cell growth and reduces the replication mechanism and viability of cancer cells or tumor cells. Vitamin $C$ can act as an anticancer agent because it can cause cancer cell death through the stabilization of p53 protein (Gonzales et al., 2014). Further studies reported that combining vitamin $\mathrm{C}$ with 5 -fluorouracil, sodium d-ascorbate, cyclophosphamide, paclitaxel, arsenic trioxide, doxorubicin, and radiation could sensitize cancer cells to anticancer drugs and increase the success rate of chemotherapy or radiotherapy. The clinical evaluation confirms the positive effect of vitamin C on improving quality of life in 30-95\% of cancer patients during chemotherapy/radiotherapy procedures (Wilson et al., 2014).

Recent research is currently studying the effect of combination treatment of vitamin $\mathrm{C}$ with cisplatin on gastric cancer cells. It will introduce new treatment strategies regarding the efficacy and side effects of cisplatin. The results showed that vitamin $\mathrm{C}$ alone and the combination of vitamin C with cisplatin could increase the percentage of cells in the sub-G0 phase compared to cisplatin alone. In addition, treatment of gastric cancer cells with vitamin $\mathrm{C}$ alone and in combination with vitamin $\mathrm{C}$ with cisplatin led to an increase in the percentage of apoptotic and necrotic cancer cells, compared with negative controls and cisplatin alone treatment. The findings of the current study suggest that co-administration of vitamin $C$ with cisplatin could be developed as an innovative and effective therapeutic strategy for patients with gastric cancer in the future (Ghavami \& Sardari, 2020).

High doses of vitamin C in breast cancer cells are cytotoxic to MCF7 and MDA-MB231 cells (Melzer et al., 2021). In its use, vitamin $C$ can be combined with Somatostatin, a natural peptide that has a growth inhibitory effect in several breast cancer models (Hanikoglu et al., 2019).

Telomeres are nucleotide replications at the ends of chromosomes that function to maintain genome stability, regulate replication and cell death. Telomeres regularly shorten or shrink at each cell replication (Lu et al., 2011; Svenson et al., 2008). Most cancer cells will escape this limitation by activating telomerase which can maintain telomere length (Noureini et al., 2018). On the other hand, it is known that individuals with shorter telomeres are at a higher risk of developing various types of cancer (Svenson et al., 2008).

In MCF-7 breast cancer cells, Chelidonium administration can affect telomere length, telomere stability, and telomerase inhibition which depends on dose and time (Svenson et al., 2008). The effect of vitamin C administration on telomere length and telomerase activity in MCF-7 breast cancer cells is not yet known. To support this research, it is necessary to know the cytotoxic effect 
of vitamin C on MCF-7 cells associated with telomerase expression. The study aimed to determine the cytotoxicity effect of vitamin C on MCF-7 breast cancer cells.

\section{Material and Methods}

The materials were cell line MCF-7 (FKUI Integrated Lab), vitamin C (TCI), and materials for cell culture media such as Fetal Bovine Serum (FBS) 0.5\% (Gibco), Rosewell culture media Park Memorial Institute (RPMI) (Gibco), Dulbecco's Minimum Essential Medium (DMEM) (Gibco), hydroxyethyl piperazineethanesulfonic acid (HEPES) (Sigma), kit for union MTS (Promega).

\section{MTS test (3-4;5-dimethythiazole-2-yl)-5-(3-carboxymetoxyphenyl)2-(4-sulfophenyl)-2H- tetrazolium)}

The MTS assay was used for cytotoxicity by calculating the viability of MCF-7 cells, performed according to the Kit CellTiter96AQueous Non-RadioactiveCell ProliferationAssay Technical Bulletin protocol. The MTS test was carried out by first growing cells using 2 (two) well plates with 96 wells, only media was given to each well, then a well containing 1 x 104 cells/cells was added to each well with three replications each. The composition of the well plate is media, media with cells only, media with serial concentrations of vitamin C 10, 20, 40, 80,160, and $320 \mathrm{~g} / \mathrm{mL}$. The treatment with vitamin C was carried out after the cells were incubated in plates for 24 hours. The first plate was incubated for 24 hours after administration of vitamin $\mathrm{C}$ and the second plate was incubated for 48 hours after administration of vitamin C.

\section{Statistic analysis}

IC50 value and percentage of cell viability calculated using SPSS version 22 with regression correlation test $(\mathrm{p}<0.05)$

\section{Results and Discussion \\ Result}

The results of the calculation of the percentage inhibition of growth in the form of the percentage of viability of MCF-7 cells due to the administration of 6 doses of vitamin C from 10 $\mathrm{g} / \mathrm{mL}, 20 \mathrm{~g} / \mathrm{mL}, 40 \mathrm{~g} / \mathrm{mL} \mathrm{g} / \mathrm{mL}, 80 \mathrm{~g} / \mathrm{mL}, 160 \mathrm{~g} / \mathrm{ml}$, and $320 \mathrm{~g} / \mathrm{mL}$. The viability of cultures incubated for 24 hours and 48 hours is presented in Figure 1.

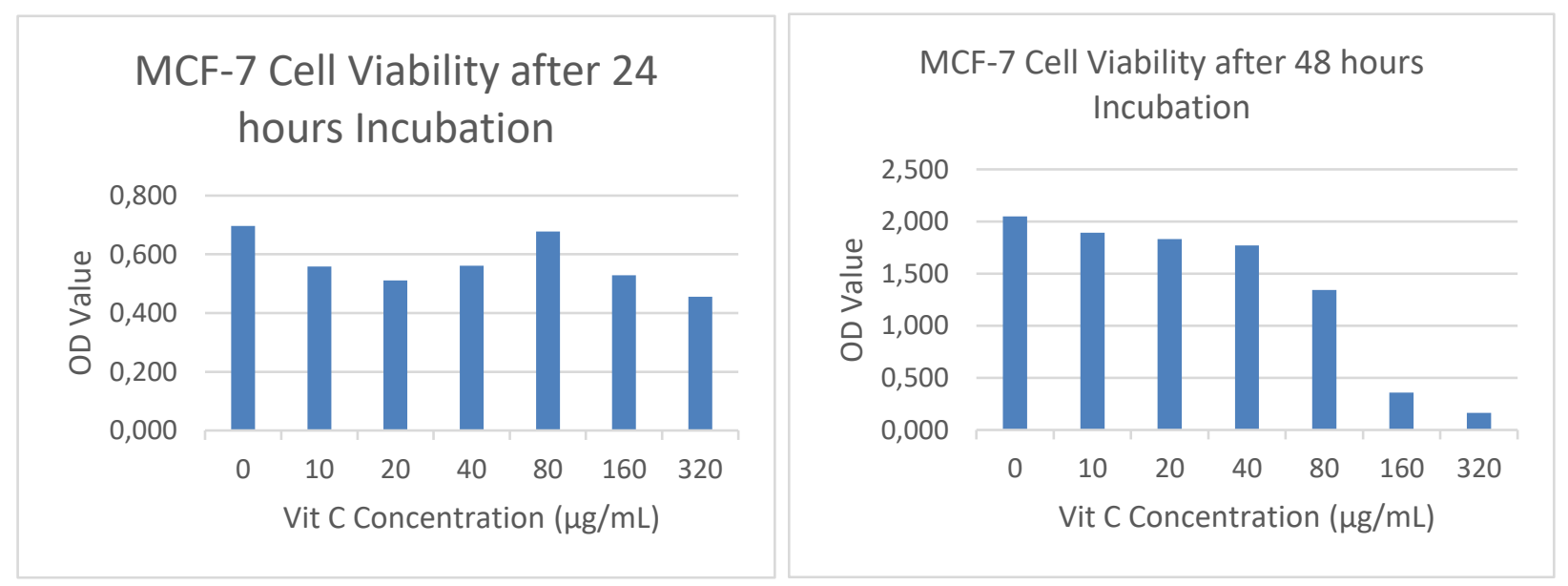

Figure 1. Viability of MCF-7 cells at incubation 24 and 48 hours after administration of vitamin C

The smallest percentage of viability in 24-hour culture was $86.75 \%$ at a dose of $320 \mathrm{~g} / \mathrm{mL}$ and in a 48 -hour culture, it was $7.95 \%$ at a dose of $320 \mathrm{~g} / \mathrm{mL}$. The straight-line regression equation for 
the prediction of IC50 dose of vitamin C processed from incubation 48 hours after vitamin C treatment (Figure 2) is;

$$
y=93.39-0.31 x
$$

With an R2 value of 0.89 , the IC50 value of vitamin C was $140 \mu \mathrm{g} / \mathrm{mL}$.

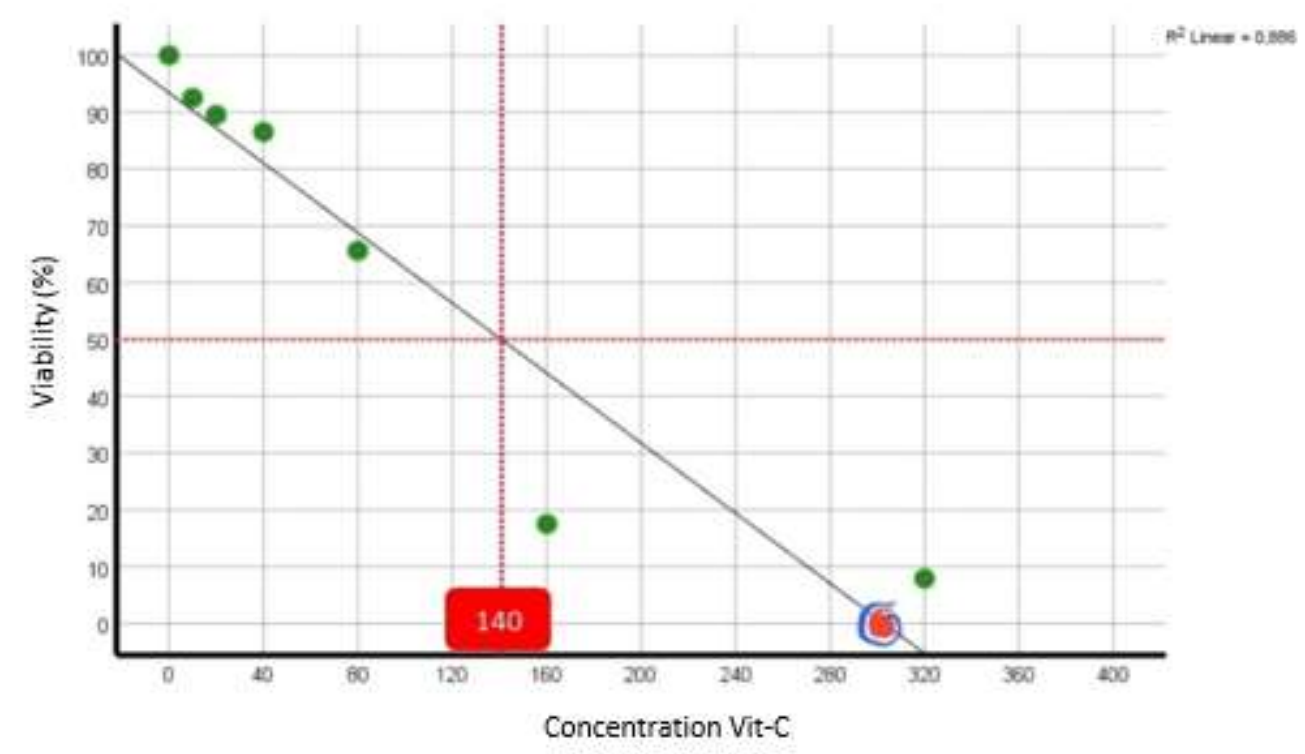

Figure 2. The regression equation for prediction of IC50 dose of vitamin C in MCF-7. cell culture

\section{Discussion}

The administration of vitamin C had an inhibitory effect on the growth of MCF-7 cancer cells which was indicated by a decrease in their viability. At 24 hours incubation, the decrease in viability varied from the dose used, while at 48 hours incubation there was a tendency to decrease the viability of MCF-7 cells with increasing doses. The smallest viability occurred at the largest dose of $320 \mathrm{~g} / \mathrm{mL}$ (Figure 1). From the two incubation data above, incubation 48 hours after administration of vitamin $C$ gave a better inhibitory effect on cell proliferation.

From these results, it is known that vitamin C has a cytotoxic effect on MCF-7 breast cancer cells. Thus, vitamin $\mathrm{C}$ has a chance as an anti-breast cancer ingredient. There is a tendency, the higher the dose of vitamin C, the greater the cytotoxic effect. Likewise, the inhibition of MCF-7 cell proliferation will be greater with increasing doses of vitamin $\mathrm{C}$.

This is in line with other studies that reported that vitamin $C$ could induce cytotoxic effects on cancer cells but did not induce cytotoxic effects on normal cells. It was reported that this cytotoxic effect is related to the pro-oxidant properties of vitamin $\mathrm{C}$, which can activate the transcription factor NF-kappa B and inhibit cell growth. In addition, by producing hydrogen peroxide and activating hydroxyl radicals, vitamin $\mathrm{C}$ can reduce cell replication mechanisms and cancer cell viability by inducing DNA strand damage, controlling mitotic activity, and damaging mitochondria and cell membranes (Lee, 2009; Gonzales et al., 2014).

The administration of vitamin $C$ in either a single dose or a combination dose can increase the percentage of apoptosis and necrotic cancer cells. In addition, single doses of vitamin $\mathrm{C}$ or combination doses can also cause cancer cells to be sensitive to anticancer drugs and chemotherapy (Ohno et al., 2009; Wilson et al., 2014). 
High doses of vitamin $\mathrm{C}$ in combination with conventional cancer drugs on all breast cancer cell lines, especially MCF-7 have therapeutic advantages against breast cancer cells. High doses of vitamin $C$ combined with tamoxifen, eribulin mesylate, fulvestrant, and trastuzumab decreased MCF-7 cell viability compared to chemotherapy or endocrine therapy alone (Lee et al., 2019). A similar study using a combination of vitamin C with tamoxifen on MCF-7 cells can increase the expression of FasL and TNF- (Subramani et al., 2014).

Another study that used a combination of vitamin C with somatostatin on MCF-7 and MDAMB231 breast cancer cells caused membrane remodeling in MCF-7 cells that could affect signaling processes. In MCF-7 cells the combination of vitamin $\mathrm{C}$ and somatostatin significantly decreased EGFR (Epidermal Growth Factor Receptors) and MAPK (Mitogen-Activated Protein Kinase) signaling compared to MDA-MB231 cells (Hanikoglu et al., 2019).

Vitamin C increased apoptosis of MDA-MB231 breast cancer cells by inducing the expression of the TRAIL gene (TNF-related apoptosis-inducing ligand). Furthermore, vitamin $\mathrm{C}$ will increase the activation of Bax and caspase, reduce Bcl-xL and increase the release of cytochrome C. Thus, vitamin $C$ has potential as a therapeutic agent and cancer prevention (Sant et al., 2018).

In another study on breast cancer cells MDA-MB231 and Bcap37, several concentrations of vitamin $C$ gave different effects. Low and moderate concentrations of vitamin $C$ increased migration and invasion of breast cancer cells, but high concentrations of vitamin $\mathrm{C}$ inhibited migration and invasion of breast cancer cells significantly. High doses of vitamin C increase E cadherin and decrease vimentin which will suppress mesenchymal-epithelial transition (EMT) in breast cancer cells (Zeng et al., 2019).

Chelidonine administration inhibited the growth of MCF-7 cells and caused telomere shortening and inhibited telomerase compared to controls. Telomerase (hTERT/Human Telomerase Reverse Transcriptase) inhibition is dose and time-dependent. It was concluded that the administration of chelidonine to breast cancer cells can affect telomere length and telomere stability (Noureini et al., 2018).

\section{Conclusion}

Vitamin C has a cytotoxic effect on MCF-7 cancer cells with an IC50 value of $140 \mathrm{~g} / \mathrm{mL}$. Further research is needed to determine the effectiveness of vitamin $C$ on the expression of the telomerase enzyme in breast cancer cells, especially MCF-7.

\section{Acknowledgment}

The author thanks YARSI University for the 2019/2020 Internal Grant fund

\section{References}

Bartosz. I. S., \& Bartosz, G. (2014). Effects of antioxidants supplementation on ging longevity. BioMed Res Int, 3, 40468. doi: $10.1155 / 2014 / 404680$.

Benson, J. R., \& Jatoi, I. (2012). The global breast cancer burden. Future Oncol, 8(6), 697 - 702. Doi: 10.2217/fon.12.61

Fitriatuzakiyah, N., Rano, K., Sinumeraya, Irma, M., \& Puspitasari. (2017). Terapi Kanker dengan radioterapi dan perkembangannya di Indonesia. J Farm Klin Ind, 6(4), 311-320. Doi: https://doi.org/10.15416/ijcp.2017.6.4.311

Ghanem, A., Melzer, M., Zaal, E., Neises, L., Baltssen, D., Matar, O., Glennemeier-Marke, H., Almouhanna, F., Theobald, J., El Maaty, M. A. A., Berkers, C., \& Wolfl, S. (2021). Ascorbat kills breast cancer cells by rewiring metabolism via redox imbalance and energy crisi. Free radix Biol Med, 163, 196-209. doi: 10.1016/j.freeradbiomed.2020.12.012.

Ghavami, G., \& Sadar, S. (2020). Synergistic effect of vitamin cwith cisplastin for inhibiting proliferation of gastric cancer cells. Iran Biomed J, 24(2), 119-127. doi: 10.29252/ibj.24.2.119.

Gonzales, M. J., Miranda-Masori, J. R., \& Jorge, R. (2014). Insight of vitamin C and cancer. London: Springer

Hanikoglu, A., Kucuksayan, E., Hanikoglu, F., Ozben, T., Menounou, G., Sansone, A., Catgilialoglu, C., Bella, G. D., \& Ferreri, C. (2019). Effects of somatostatin and vitamin C on Fatty Acid Profile of Breast Cancer Cell Membrane. Anticancer Agents Med Chem., 19(15), 1899 - 1909. doi: 10.2174/1871520619666190930130732. 
Harper, L, Costea, D. E., Gammon, L, Fazil, B., Biddle, A., \& Mackenzie, I. C. (2010). Normal and malignant epithelial cells with stem like properties have and extended G2 cell cycle phased associated with apoptotic resistence. BMC Cancer, 10, 1471-1477. https://doi.org/10.1186/1471-2407-10-166

Lee, W. J. (2009). The prospect of Vitamin C in cancer therapy. Immune Network, 9(5), 147-152. doi: 10.4110/in.2009.9.5.14

Lee, S. J., Jeung, J. H., Lee, I. h., Lee, J., Jung, J. H., Park, H. Y., Lee, D. H., \& Chae, J. S. (2019). Effects of high dose vitamin C combined with anticancer treatment on breast cancer Cells. Anticancer Res, 39(2), 751-758. Doi: 10.21873/anticanres.13172

Lu, L., Zhang, C., Zhu, G., Irwin, M., Risch, H., Menato, G., Mitidieri, M., Katsaros, D., \& Yu, H. (2011). Telomerase expression and telomere length in breast cancer and their association with adjuvant treatment and disease outcome. Breast Cancer Res ,6(13), R56. doi: 10.1186/bcr2893.

Momenivahed, Z., \& Salehiniya, H. (2017). Incidence, Mortality and Risk factors of cervical cancer in the world. Biomed Res Ther, 4(120), 1795-1811

Momenivahed, Z, \& salehiniya, H. (2019). Epidemological characteristics of and Risk factors to breast cancer in the world. Breast Cancer-Target- Ther, 1, 151-164

Mutebi, M., Anderson, B. O., Duggan, C., Adebamowo, C., Agarwal, G., Ali, Z., et al. (2020). Breast cancer treatment, A phased approach to implementation. Cancer 126 Suppl, 10, 2365 - 2378. doi: 10.1002/cncr.32910.

Nourieni, S. K., Fatemi, L., \& Wink, M. (2018). Telomere Shortening in breast cancer cells (MCF-7) undertreatment with low dose of the benzylisoquinoline alkaloid chelidonne. PLOS ONE, 13(10), e0204901. doi: 10.1371/journal.pone.0204901

Sant, D. W., Mustafi, S., Gustafson, C. B., Chen, J., Sfingerland, J. M., \& Wang, G. (2018). Vitamin C promotes apoptosis in breast cancer Cells by increasing TRAIL expression. Sci Report, 8(1), 5306. doi: 10.1038/s41598-018-23714-7.

Subramani, T., Yeap, S. K., Ho, W. Y., Ho, C. L., Omar, A. R., Aziz, S. A., Rahman, N. M. A. N. K., \& Aitheen, N. B. (2014). Viamin C su presses cell death in MCF-7 human breast cancer cells induced by amoxifen. J Cell Mol Med, 18(2), 305-313

Sung, H, Ferlay J, Siegel RL, Laversone L, Soeyamataram I, Jemal A, Bray F 2021. Global Cancer Statistics 2020: GLOBOCAN Estimates of Incidence and mortality world wide for 36 cancaer in 185 Countries. CA Cancer J Clin, 71, 209-249. Doi: 10.1111/jcmm.12188

Svenson, U., Nordfjall, K., Stegmayor, B., Manjer, J., Nelson, P., Tavelin, B., Henrikson, R., Lenner, P., \& Raos, G. (2008). Breast cancer Survival is Associated with telomere length in peripheral blood cells. Cancer Res, 15(68), 3618-3623. doi: 10.1158/00085472.CAN-07-6497.

Ohno, S., Ohno, Y., Suuki, N., Soma, G., \& Inoue, M. (2009). High dose vitamin C therapy in the treatment of patient with advanced cancer. Anticancer Res, 29(3), 809 - 816

Phaniendra, A., Jestadi, D. B., \& Peryasami, L. (2015). Free radicals: Properties sources targetand their implication invarious diseases. Indian j Clin Biochem, 31(2),11- 26. Doi: 10.1007/s12291-014-0446-0

Putra, A., Tjahjono, \& Winarto. (2011). Ekstrak keladi tikus (Typhonium flagelliforme) fraksi diklorometanolik dan ekspresi caspase-3 dan 21 cell line kanker payudara MCF-7. M Med Indones, 45, 95-104.

Rao, R. S., \& Moller, L. M. (2011). Pattern of occurence and occupancy of carbonylation sites in proteins. Proteomics, 11(21), 4166 4173. https://doi.org/10.1002/pmic.201100223

Wilson, M. K., Baguley, B, C., Wall, C, Jameson, M. B., \& Findloy, M.P. (2014). Review of high dose intravenous vitamin C as an Anticancer agent. Asia Oac J Clin Oncol, 10(1), 22 -3. doi: 10.1111/ajco.12173.

Zendehdel, M., Niakin, B., Keshtkar, A., Rafiri, E., \& Salamah, F. (2018). Subtype of benign breast disease as risk factor for breast cancer: A systematic review and Meta-Analysis Protocol. Iran J Med Sci, 43(1), 1-8

Zeng, L. H., Wang, Q. M., Feng, L. Y., Ke, Y. D., Zu, Q. Z., Wei, A. Y., Zhang, C, \& Zing, R. B. (2019). High dose vitamin C suppresses the invation and metastasis of breast cancer cells via inhibiting epithelial-mesenchymal transition. Onco Target- Ther, 12, 74057413. Doi https://doi.org/10.2147/OTT.S222702 